\title{
PENINGKATAN PEMAHAMAN PENANGANAN KESEHATAN MENTAL INTEGRATIF (PSIKOLOGI DAN KEISLAMAN) MELALUI VIDEO PROMOTIF
}

\author{
Fuji Astutik \\ Fakultas psikologi, Universitas Islam Negeri Malang \\ Email: fujiastutik@uin-malang.ac.id
}

\begin{abstract}
This research aims to find out the improved understanding of integrative mental health treatment (psychological and islamic) through promotive videos. This research method uses the one group pretest-posttest design experiment. The research sample is 61 people which is $25 \%$ of the population. The result of the study confirms that there is a significant increase indicated by the significance of $0.001<0.005$. In addition, the $t$-count is also greater than the t-table which is 3,521 and the $t$ count is 2,660. The conclusion of this study is that the promotion of mental health treatment that is integrated between science and islam is proven effective by using promotive video.
\end{abstract}

Keywords: Understanding, Mental Health, Video, Integration

\begin{abstract}
ABSTRAK
Tujuan penelitian ini adalah untuk mengetahui peningkatan pemahaman penanganan kesehatan mental integrative (psikologi dan keislaman) melalui video promotif. Metode penelitian ini menggunakan eksperimen the one group pretest-posttest design. Sampel dari penelitian berjumlah 61 orang yang merupakan 25\% dari populasi. Hasil penelitian menemukan bahwa ada peningkatan yang signifikan ditunjukkan dengan angka signifikansi $0,001<0,005$. Selain itu thitung juga lebih besar dari t tabel yaitu 3,521 dan t hitung sebesar 2,660. Kesimpulan dari penelitian ini adalah promosi penanganan Kesehatan mental yang terintegrasi antara sains dan keislaman terbukti efektif dilakukan dengan menggunakan video promotif.
\end{abstract}

Kata Kunci: Pemahaman, Kesehatan mental, Video, Integrasi

\section{PENDAHULUAN}

Isu mengenai Kesehatan mental sudah menjadi fokus seiring berkembangnya zaman dan teknologi. Kesehatan mental merupakan isu yang menjadi fokus perhatian di WHO dengan adanya peringatan hari kesehatan mental dunia yang diperingati setiap tanggal 10 oktober. Berbagai macam kegiatan dilakukan untuk memberikan informasi tentang Kesehatan mental. Data dari kompasiana pada tanggal 9 oktober 2020 bahwa data global dari WHO menyebutkan ada empat ratus lima puluh juta individu terkena gangguan jiwa. Selain itu angka bunuh diri mencapai satu juta orang yang melakukan bunuh diri dalam satu tahun. Di negara Indonesia terdapat 14 juta orang mengalami gangguan psikologis (Kompasiana, 2019).

Beberapa penelitian tentang kesehatan mental telah dilakukan. Seperti hasil penelitian menemukan bahwa promosi kesehatan mental berbasis sekolah dan 
komunitas cukup efektif untuk dilakukan Barry M. Margaret.et.al (2013). Selain itu penelitian lain dilakukan untuk pengembangan sistem promosi Kesehatan mental melalui internet dan face to face pada anak sekolah menengah pertama (Eschenbeck. et.al., 2019).

Jika dikaitkan dengan tingginya angka gangguan psikologi di Indonesia maka dirasa perlu untuk melakukan satu bentuk pengembangan pemahaman Kesehatan mental menggunakan video promotif. Video dijadikan sebagai media untuk memahamkan masyarakat mengenai kesehatan mental. Selain itu apa yang perlu dilakukan ketika seseorang mengalami gangguan psikologis. Penelitian mengenai penggunaan video dalam pemberian pemahaman seringkali dilakukan pada anak-anak. Seperti penelitian yang dilakukan oleh Cheong Yin Sng, Mark. C \& Jennifer Stephenson (2013) bahwa penggunaan video modeling dan audio lebih efektif daripada menggunakan media visual pada anak dengan spektrum autis. Pada penelitian kali ini, peneliti menggunakan video yang akan diterapkan pada orang dewasa.

Karakteristik masyarakat Indonesia yang erat kaitannya dengan nilai-nilai agama. Jika dikaitkan dengan penganut agama di Indonesia, mayoritas penduduk menganut agama Islam. Oleh karena itu, isi dari video promosi berkaitan dengan pemahaman penanganan Kesehatan mental integrasi antara sains dan keislaman.

Integrasi diartikan sebagai satu proses menyatukan sains dan islam menjadi satu kesatuan yang utuh Poerwadarminto (1986). Berkaitan dengan integrasi keilmuan dalam perguruan tinggi Husnia (2015) menyatakan bahwa konsep ini sudah diterapkan di dalam pesantren dengan cara memberikan muatan pembelajaran Islam dan umum.

Maksud dari kata integrasi diatas adalah kurang lebih sama dengan konsep islamisasi. Karena keduanya memiliki tujuan untuk sama-sama mengaitkan antara ilmu dan agama untuk menemukan pandangan atau paradigma baru Husnia (2015) memaparkan bahwa setidaknya ada empat paradigma tentang integrasi yang diambil dari berbagai pemikiran para tokoh. Pertama integrasi teologis yang berupaya untuk mencari contoh atau implikasi teologi dari berbagai teori-teori baru yang ilmiah serta membangun satu bangunan teologi yang tepat berlandaskan pada teologi yang tradisional. Kedua yaitu menempatkan agama sebagai pendukung seluruh kegiatan ilmiah. Ketiga islamisasi ilmu yaitu sebuah ilmu hendaknya dibersihkan dengan menempatkan wahyu dan intuisi sebagai sesuatu yang otoritas. Keempat yaitu bahwa proses islamisasi 
merupakan gerakan kajian keilmuan timbal balik antara konteks menuju teks begitu juga sebaliknya. Jika disimpulkan beberapa kajian di atas maka integrasi adalah proses penyatuan antara islam dan keilmuan dengan cara yang sesuai dengan kebutuhan namun didalamnya harus terdiri atas dua muatan tersebut.

Pemahaman merupakan satu bentuk kemampuan seseorang dalam memberikan interpretasi dan menyebutkan kembali informasi yang didapatkan dari luar menggunakan bahasa sendiri Bloom (dalam Djaali 2011). Lebih lanjut Bloom (dalam Djaali 2011). menyatakan bahwa pemahaman berarti seseorang mampu untuk memahami materi atau bahan tertentu yang sedang dipelajari. Kemampuan tersebut terdiri dari beberapa hal; pertama yaitu kemampuan translasi. Kemampuan Translasi merupakan kemampuan seseorang dalam merubah tanda atau simbol tertentu dalam bentuk yang berbeda. Kedua yaitu kemampuan menginterpretasi yaitu kemampuan seseorang dalam menjelaskan tentang apa yang sedang ia pelajari. Ketiga yaitu kemampuan mengektrapolasi yaitu kemampuan seseorang dalam memberikan penjabaran yang lebih luas arti dari sebuah materi yang sedang dipelajari. Pada kondisi ini seseorang mampu untuk memberikan jawaban pertanyaan dengan menggunakan bahasa sendiri, misalnya dengan memberikan contoh baik secara konsep maupun prinsip.

Selain itu, kata kerja yang akan muncul pada fase ini terdiri dari: kemampuan memberikan penjelasan, memperkirakan sesuatu, menjelaskan sesuai dengan informasi yang didapatkan, mengkategorikan sesuai dengan bentuk, jumlah dan lain sebagainya, merinci dengan jelas, menghubungkan atau mengasosiasikan antar satu informasi dengan informasi yang lain, memahami ciri dari informasi tersebut, membuat perbandingan, menghitung, memberikan uraian, menjalin, membedakan antara satu materi dengan yang lain, mempertahankan informasi yang telah didapatkan, menjabarkan dengan jelas dan mampu untuk mengkontraskan apa yang dipelajari. Berkaitan dengan pemahaman pengetahuan, seseorang akan melihat sesuatu yang berbentuk simbol yang kemudian diolah dalam kognisi sehingga memunculkan sesuatu hal baru dalam dirinya.

Sebagaimana yang dikatakan Bandura (dalam Hergenhahn 2009) bahwa sebuah tanda atau simbol yang didapatkan dari modelling video akan menjadi satu template atau cetakan akan dijadikan sebagai perbandingan dari tindakan tertentu. Pada saat melihat sebuah video, 
maka seseorang akan melihat perilakunya sendiri dan akan membandingkan dengan apa yang dilakukan oleh model dalam video tersebut. James (2003) menyatakan bahwa video merupakan salah satu cara untuk mendemonstrasikan perilaku baik secara kelompok maupun perorangan yang dilakukan oleh seorang konselor. Metode ini juga dapat digunakan dalam berbagai setting yaitu olahraga, kegiatan preventif, pengobatan medis, industri organisasi dan setting klinis. Branham (dalam Avcioglu 2013) bahwa metode ini dilakukan di berbagai lingkungan bisa di rumah ataupun di kelas.

Promosi kesehatan mental tidak hanya diberikan kepada mereka yang memiliki masalah dalam Kesehatan mental. Namun juga sebagai upaya untuk pencegahan agar tidak mengalami masalah dalam kesehatan mental. Promosi kesehatan mental berfokus pada peningkatan kekuatan, kapasitas sumber daya individu dan masyarakat untuk memungkinkan mereka meningkatkan control atas kesehatan mental mereka Barry \& Jenkins (2007). Penelitian menemukan bahwa kaum muda menjadikan internet sebagai alat untuk meningkatkan kesehatan mental dan kesejahteraan mereka. Blanchard, et al. (2011); Rickwood (2010).

\section{METODE}

Penelitian ini menggunakan jenis penelitian eksperimen dengan designs the one group pretest-posttest yaitu subjek diberi pretest dan setelah itu diberikan video untuk ditonton selanjutnya diberikan postest untuk mengetahui keadaan awal adakah perbedaan dengan setelahnya. Video diupload melalui channel Youtube dan subjek diminta untuk mengisi lembar pretest terlebih dahulu. Setelah diminta menonton video subjek dalam penelitian ini diberikan lembar postes. Pemberian soal pada pretest dan postes dilakukan dalam waktu yang sama. Penelitian dilakukan dengan menggunakan sampel mahasiswa yang berjumlah 61 orang. Subjek ini diambil dari $25 \%$ populasi dalam penelitian ini. Pengambilan sampel ini mengacu pada pendapat dari Arikunto (2016) bahwa jika populasi subjek yang diteliti kurang dari seratus, maka diambil semua. Namun jika populasi lebih dari seratus maka diambil persentase yaitu $10-15 \%$ atau $15-25 \%$.

\section{HASIL}

Penelitian ini bertujuan untuk mengetahui perbedaan pemahaman kesehatan mental integratif (sains dan keislaman) melalui video promotif. Penelitian ini menggunakan analisis uji $\mathrm{t}$ menggunakan SPSS for windows versi 16.00. Penggunaan Uji t pada hasil pre dan 
postes kelas eksperimen adalah untuk mengetahui peningkatan skor. Penelitian akan dinyatakan memiliki hasil signifikan jika $\mathrm{t}$ hitung lebih besar dari t tabel pada taraf signifikansi 5\% dan nilai p. Hasil penelitian menunjukkan nilai Sig. (2-tailed) 0,001 yang mana hasil tersebut lebih kecil dari 0,005, oleh karena itu data menunjukkan bahwa ada perbedaan yang nyata nilai pretes dan postes terhadap peningkatan pemahaman kesehatan mental integrative (sains dan keislaman) melalui video promotif.

Hasil lain berdasarkan $\mathrm{t}$ hitung dengan menggunakan rumus $(\mathrm{a} / 2)$ : df yaitu (0,05/2): 60 didapatkan hasil 2,660.t hitung pada tabel menunjukkan angka - 3,521. Tanda negatif pada $t$ hitung bukan menunjukkan hasil yang negatif, namun hal itu disebabkan karena hasil pretes yang lebih rendah dari posttest. Oleh karena itu dapat dikatakan bahwa $\mathrm{t}$ hitung bernilai positif. Berdasarkan angka tersebut maka didapatkan bahwa $\mathrm{t}$ hitung $>\mathrm{t}$ tabel, maka dapat ditarik kesimpulan jika ada pengetahuan yang berbeda dari subjek antara sebelum dan sesudah menonton video.

\section{PEMBAHASAN}

Hasil diatas sesuai dengan yang dikatakan James (2003) bahwa vidio merupakan salah satu cara untuk mendemonstrasikan perilaku baik secara kelompok maupun perorangan yang dilakukan oleh seorang konselor. Metode ini juga dapat digunakan dalam berbagai setting yaitu olahraga, kegiatan preventif, pengobatan medis, industri organisasi dan setting klinis. Branham (dalam Avcioglu 2013) bahwa metode ini dilakukan diberbagai lingkungan bisa di rumah ataupun di kelas. Penelitian ini menunjukkan bahwa viewers melihat isi video dan mereka memahami apa yang berada didalamnya seperti yang dikatakan oleh Bandura (dalam Hergenhahn 2009), bahwa simbol atau tanda tertentu yang didapatkan melalui modelling video akan menjadi pencetak perilaku baru yang akan dibandingkan dengan perilaku dari si penonton video. Pada saat menonton video, maka seseorang akan melihat perilakunya sendiri dan akan membandingkan dengan perilaku dari video yang ditonton. Ketika ada perilaku yang berbeda dengan yang ditonton maka akan ada koreksi atas perilakunya sendiri. Proses koreksi akan terus terjadi sampai ada kesesuaian dengan perilaku model yang ada dalam video. Jadi peningkatan pengetahuan ini diawali dengan melakukan koreksi diri atas pengetahuan sebelumnya dan pengetahuan setelahnya. 


\section{PENUTUP}

Setelah dilakukan analisis maka didapatkan hasil bahwa ada perbedaan pemahaman antara sebelum dan sesudah menonton video. Perbedaan hasil ini menunjukkan bahwa peningkatan pemahaman penanganan Kesehatan mental integratif (sains dan keislaman) dapat dilakukan dengan video promotif. Pengetahuan selalu berevolusi sehingga dibutuhkan untuk selalu apa penelitian yang berkelanjutan. Adapun saran untuk peneliti selanjutnya adalah untuk membuat desain eksperimen yang berbeda tidak hanya melihat dari pre post, namun juga bisa dilakukan dengan menggunakan kelompok kontrol dan kelompok eksperimen. Selain itu disarankan untuk memperpanjang pengamatan untuk bisa melihat variabel lain yang bisa menjadi faktor prediktor atau bahkan yang memberikan pengaruh pengetahuan.

\section{DAFTAR PUSTAKA}

Anderson, J. C., \& Gerbing, D. W. Structural Equation Modeling in Practic: A Review and recommended two step approach. Psychological Bulletin.

Arikunto, S. (2006). Prosedur Penelitian Suatu Pendekatan Praktik. Jakarta: Rineka

Avcioglu, H. (2013). Effectiveness of Video Modeling in Training Students With Intellectual Disabilities to great people when they meet. Journal ERIC.

Barry, M. M., \& Jenkins, R. (2007). Implementing Mental Health Promotion. Oxford: Churchill Livingstone

Blanchard, M. (2011). Navigating the digital disconnect: understanding the use of information communication technologies by the youth health workforce to improve young people's mental health and wellbeing. Melbourne: Orygen Youth Health Research Centre, University of Melbourne.

Djaali. (2011). Psikologi Pendidikan. Jakarta: Bumi aksara

Eshenbeck., H., Lehner, L., et.al. (2019). School-based mental health promotion in children and adolescents with StresSOS using online or face-to-face interventions: study protocol for a randomized controlled trial within the ProHEAD Consortium. US national library of medicine national institutes of health.

Hergenhan, B. R., \& Olson, M. (2009). Theories of learning. Jakarta: Prenada Media Grup

Salamah, H. (2015). Landasan Fondasional Integrasi Keilmuan di UIN Maulana Malik Ibrahim Malang. Jurnal: ISLAMICA. Vol. 10.

Rickwood, D. (2010). Promoting Youth Mental Health Through Computer Mediated Communication. International Journal of Mental Health Promotion.

Cheong, Y. S., Carter, M., Stephenson, J.. (2013). A review of video Modelling and Scripts in teaching conversational Skills to individuals with autism Spectrum Disorders. Journal Springer science business Media New York. 